\title{
The effects of microfluidization on the physical, microbial, chemical, and coagulation properties of milk
}

\author{
A. J. Bucci, ${ }^{1}$ D. L. Van Hekken, M. H. Tunick, ${ }^{2}$ J. A. Renye, and P. M. Tomasula \\ Eastern Regional Research Center, Dairy \& Functional Foods Research Unit, USDA, Agricultural Research Service (ARS), Wyndmoor, PA 19038
}

\begin{abstract}
This work examines the use of mild heat treatments in conjunction with 2-pass microfluidization to generate cheese milk for potential use in soft cheeses, such as Queso Fresco. Raw, thermized, and high temperature, short time pasteurized milk samples, standardized to the $3 \%$ (wt/wt) fat content used in cheesemaking, were processed at 4 inlet temperature and pressure conditions: $42^{\circ} \mathrm{C} / 75 \mathrm{MPa}, 42^{\circ} \mathrm{C} / 125 \mathrm{MPa}, 54^{\circ} \mathrm{C} / 125 \mathrm{MPa}$, and $54^{\circ} \mathrm{C} / 170 \mathrm{MPa}$. Processing-induced changes in the physical, chemical, and microbial properties resulting from the intense pressure, shear, and cavitation that milk experiences as it is microfluidized were compared with nonmicrofluidized controls. A pressure-dependent increase in exit temperature was observed for all microfluidized samples, with inactivation of alkaline phosphatase in raw and thermized samples at 125 and $170 \mathrm{MPa}$. Microfluidization of all samples under the 4 inlet temperature and processing pressure conditions resulted in a stable emulsion of fat droplets ranging from 0.390 to $0.501 \mu \mathrm{m}$, compared with 7.921 (control) and 4.127 (homogenized control) $\mu \mathrm{m}$. Confocal imaging showed coalescence of scattered fat agglomerates 1 to 3 $\mu \mathrm{m}$ in size during the first $24 \mathrm{~h}$. We found no changes in fat, lactose, ash content or $\mathrm{pH}$, indicating the major components of milk remained unaffected by microfluidization. However, the apparent protein content was reduced from 3.1 to $2.2 \%$, likely a result of near infrared spectroscopy improperly identifying the micellar fragments embedded into the fat droplets. Microbiology results indicated a decrease in mesophilic aerobic and psychrophilic milk microflora with increasing temperature and pressure, suggesting that microfluidization may eliminate bacteria. The viscosities of milk samples were similar but tended to be higher after treatment at
\end{abstract}

\footnotetext{
Received September 27, 2017.

Accepted March 29, 2018

${ }^{1}$ Corresponding author: Anthony.Bucci@ars.usda.gov

${ }^{2}$ Current address: Drexel University, Department of Culinary Arts and Food Science, 3141 Chestnut Street, Philadelphia, PA 19104.
}

$54^{\circ} \mathrm{C}$ and 125 or $170 \mathrm{MPa}$. These samples exhibited the longest coagulation times and the weakest gel firmness, indicating that formation of the casein matrix, a critical step in the production of cheese, was affected. Low temperature and pressure $\left(42^{\circ} \mathrm{C} / 75 \mathrm{MPa}\right)$ exhibited similar coagulation properties to controls. The results suggest that microfluidization at lower pressures may be used to manufacture high-moisture cheese with altered texture whereas higher pressures may result in novel dairy ingredients.

Key words: milk, microfluidization, homogenization

\section{INTRODUCTION}

Of the 14.4 billion liters of fluid milk sold in the United States in 2016, 99.99\% was pasteurized (DMI, 2017). The US FDA (2017) states that milk is legally pasteurized when heat treated at $72^{\circ} \mathrm{C}$ for $15 \mathrm{~s}$ (HTST), ensuring that the fastest moving particles meet the time and temperature combination, eliminating pathogenic bacteria and significantly reducing spoilage microflora. To address food security concerns, commercial HTST systems are often operated in excess of $75^{\circ} \mathrm{C}$ and hold times of $18 \mathrm{~s}$ (Tomasula and Kozempel, 2004). However, as the severity of heat treatment increases, changes may also occur in the dairy product quality related to color, flavor, and protein stability (Van Boekel, 1998). As a result, scientists are exploring alternative mechanisms to produce high-quality, safe, dairy products. One approach uses high pressure to eliminate pathogens and reduce spoilage microflora.

High-pressure techniques have been explored to assess their effects on specific milk components (Mohan et al., 2016) as well as in the manufacture of dairy products, including Queso Fresco (Tomasula et al., 2014), yogurt (Ciron et al., 2012), and Cheddar cheese (Devi et al., 2013). High-pressure processing methods may be operated in a batch or continuous fashion. High hydrostatic pressure, a batch process, has been used to eliminate dairy pathogens, including Escherichia coli (Styles et al., 1991), Listeria monocytogenes (Erkmen and Karataş, 1997), and Staphylococcus aureus (Patterson, 2005). However, batch processing is typically not 
practical for production of large volumes of milk-based dairy products.

Continuous high-pressure techniques may employ high-pressure homogenization valves or microfluidization. Using high-pressure homogenization valves, the inlet temperature and total pressure are key parameters to identify. Paired with the near instantaneous increase in temperature inside the homogenizer, the combined mechanical and thermal effects produce a pasteurization-like treatment (Dumay et al., 2013). In microfluidization, a stream of product enters a specially designed impact chamber with fixed geometry microchannels. Similar to high-pressure homogenization valves, the key parameters include inlet temperature, microfluidizing pressure, and number of passes. Inside the impact chamber, the stream splits, accelerating its velocity and greatly increasing the pressure. The 2 streams then collide with a combination of shear, cavitation, and turbulence eliminating pathogens, reducing spoilage microflora, and homogenizing the product. In the case of milk, microfluidization also removes the milk fat globular membrane, fractionates casein micelles, reduces the size of lipid droplets, and embeds casein fragments onto the surface of the newly formed lipid droplets (Dalgleish et al., 1996; Ciron et al., 2011).

The primary objective of our work was to examine the effects of 4 microfluidization temperature and pressure combinations on $3.0 \%$ milk. Changes in physical, microbial, chemical, and coagulation properties were compared with both 2-stage homogenized and nonhomogenized controls. The results suggested that low microfluidization pressures may be useful in the production of high-moisture cheese, whereas higher pressures can be used for novel dairy ingredients.

\section{MATERIALS AND METHODS}

\section{Milk}

Three shipments of approximately $208 \mathrm{~L}$ of raw milk and $3.8 \mathrm{~L}$ of raw heavy cream were procured from local dairies and standardized to $3.0 \%$ fat at the ERRC Dairy \& Functional Foods Research Unit dairy processing facilities in Wyndmoor, Pennsylvania, over a 6 -wk period. The standardized milk was divided into thirds, with one portion immediately refrigerated at $4^{\circ} \mathrm{C}$ until microfluidized. The remaining milk was heat treated using HTST or thermization.

\section{Processing}

Heat Treatments. Heat treatments were performed using pilot-scale processing equipment. Milk was treated using a Universal Pilot Plant (UPP; Waukesha
Cherry-Burrell, Delavan, WI) or Armfield UHT/HTST Heat Exchanger system (FT74XTS, Armfield Limited, Ringwood, UK).

After reaching thermization conditions of $65^{\circ} \mathrm{C}$ for $15 \mathrm{~s}$, one portion of the milk was processed. The product stream was then cooled to $25^{\circ} \mathrm{C}$ (UPP) or $20^{\circ} \mathrm{C}$ (Armfield UHT/HTST Heat Exchanger system) and collected into 19-L milk cans. Full cans were immediately returned to refrigeration at $4^{\circ} \mathrm{C}$ until microfluidized. Product flow rates were $40 \mathrm{~L} / \mathrm{h}$ on the Armfield UHT/HTST Heat Exchanger system and $113 \mathrm{~L} / \mathrm{h}$ on the UPP.

The remaining portion was HTST treated at $75^{\circ} \mathrm{C}$ for $15 \mathrm{~s}$. All other processing conditions were identical to thermization. Three liters each of raw, thermized, and HTST-treated milk were then warmed to $45^{\circ} \mathrm{C}$ to liquefy the milk fat,and homogenized using a 2-stage process $(10 \mathrm{MPa} / 5 \mathrm{MPa})$. Milk processed on the UPP was homogenized using a Gaulin labor-homogenizer lab 60/100 (SPX Flow Technology, Charlotte, NC), whereas milk treated on the Armfield UHT/HTST Heat Exchanger System was homogenized with a Niro Soavi NS2001 H (GE, Dusseldorf, Germany).

Microfluidization. Figure 1 shows a schematic of the microfluidization process. High-pressure processing was carried out using a Microfluidizer (M210-E/H; Microfluidics Corp., Westwood, MA). The inlet feed was supplied via a Tri-Clover PR3 positive displacement pump (Alfa-Laval, Warminster, MA) with polymer lobes and gravity fed with a 7.5-L hopper. An inlet pressure of $345 \mathrm{kPa}$ was maintained throughout testing. The hopper temperature was kept approximately 3 to $4^{\circ} \mathrm{C}$ warmer to account for heat transfer losses in the piping during flow. Hopper temperature was measured using a thermometer probe, whereas a K-type pipe clamp thermocouple (Grainger, Lake Forest, IL) connected to a temperature logger (HH309A, Omega Engineering, Stamford, CT) monitored the impact chamber inlet temperature.

Preliminary runs were performed using inlet temperatures of 10,42 , and $54^{\circ} \mathrm{C}$ at $34,75,100,125,150$, and $170 \mathrm{MPa}$ and 5 passes. No appreciable particle size reduction was observed after the second pass. It was also not possible to maintain an impact chamber inlet temperature of $10^{\circ} \mathrm{C}$ due to the temperature increase from pumping milk through the microfluidizer. At 34 $\mathrm{MPa}$, the processing time became prohibitively long, making the lowest practical pressure $75 \mathrm{MPa}$. Pressures greater than $100 \mathrm{MPa}$ resulted in microbial reduction, and at $125 \mathrm{MPa}$ and 42 or $54^{\circ} \mathrm{C}$ the exit temperatures averaged 69 and $76^{\circ} \mathrm{C}$, respectively. The highest pressures, 150 and $170 \mathrm{MPa}$, yielded conditions that could denature $\beta$-LG, reaching over $85^{\circ} \mathrm{C}$ at $170 \mathrm{MPa}$. Lastly, $170 \mathrm{MPa}$ was the highest pressure achievable on the 
6992

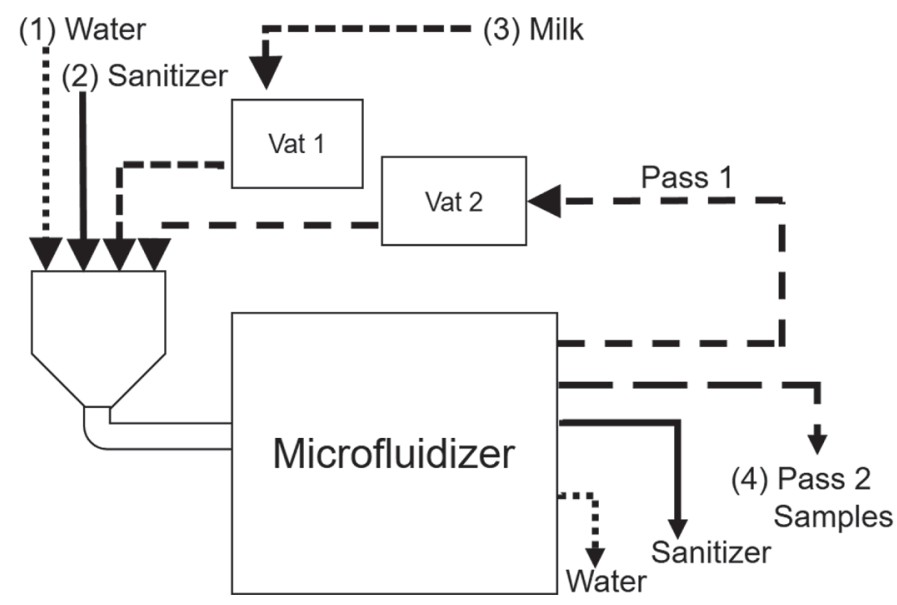

Figure 1. Schematic of microfluidization process. The system is flushed (1) with water then sanitized (2). Following sanitization, milk is added (3), processed, and collected in vat 2 . It is then microfluidized a second time and samples are collected for further analysis (4).

M210-E/H. Four microfluidization treatments, $42^{\circ} \mathrm{C} / 75$ $\mathrm{MPa}, 42^{\circ} \mathrm{C} / 125 \mathrm{MPa}, 54^{\circ} \mathrm{C} / 125 \mathrm{MPa}$, and $54^{\circ} \mathrm{C} / 170$ $\mathrm{MPa}$, were selected for further study to process raw, thermized, and HTST milk.

At the beginning of each microfluidization run, 11.4 $\mathrm{L}$ of milk were transferred from refrigerated storage $\left(4^{\circ} \mathrm{C}\right)$ and rapidly heated in a water bath until the temperature reached 3 to $4^{\circ} \mathrm{C}$ higher than the target inlet temperature. Heated raw, HTST, or thermized milk was transferred to a jacketed holding vat and agitated using an overhead mixer equipped with a paddle stirrer set to 150 RPM (OS20-Pro Digital Overhead Mixer, Scilogex LLC, Rocky Hill, CT).

To prepare for testing, the $\mathrm{M} 210-\mathrm{E} / \mathrm{H}$ was first flushed with warm water between 35 and $40^{\circ} \mathrm{C}$. Then, a minimum of $15 \mathrm{~L}$ of alkaline detergent solution (Contrex AL, Decon Labs Inc., King of Prussia, PA) between 35 to $40^{\circ} \mathrm{C}$ was run to clean the system. After flushing the detergent with warm water, $15 \mathrm{~L}$ of $8 \mathrm{~mL} / \mathrm{L}$ water sodium hypochlorite sanitizing solution (Clorox, Oakland, CA) between 35 to $40^{\circ} \mathrm{C}$ was added. During the final rinse of sanitizer, flow rates at $34 \mathrm{MPa}$ were recorded in triplicate and again after adjusting the pressure to 75,125 , or $170 \mathrm{MPa}$. Microfluidizer exit flow rates ranged from 136 to $272 \mathrm{~L} / \mathrm{h}$.

When the sanitizer reached the bottom of the hopper, milk was transferred from the holding vat to the hopper. The exit of the M210-E/H was monitored until full milk flow was achieved. Full milk flow was defined as an exit stream free of sanitizing solution. The time to full milk flow was calculated as the time it took until all detectable sanitizing solution was purged from the product stream, with a safety factor of $30 \mathrm{~s}$ added. Each treatment consisted of passing full milk flow through the M210-E/H twice. Product was collected and rapidly cooled in an ice bath to minimize the effects of thermal processing, ensuring microfluidization was the primary mechanism of change to the samples. Product was then transferred to a jacketed holding vat. When the last of the milk reached the bottom of the hopper, product milk from pass one, cooled to the correct inlet temperature, was added to refill the hopper. Pass one continued until the previously determined time until full milk flow was reached to ensure all pass one milk was purged from the system. As milk was passed through the M210-E/H for the second time, samples were collected in sterile test tubes for microbiology or a 1-L bottle and immediately chilled in an ice bath to under $10^{\circ} \mathrm{C}$. The 1-L bottle was further subdivided into smaller containers for individual assays and refrigerated $\left(4^{\circ} \mathrm{C}\right)$.

\section{Physical and Chemical Analysis}

Milk was heat treated on the first day, microfluidized on the second and third, and all assays were completed by the fifth. A full analysis and characterization of the milk samples was performed, beginning with an alkaline phosphatase test (PAS-Lite; Charm Sci. Inc., Lawrence, MA) to determine if the enzyme had been inactivated to satisfy the requirements for pasteurization. Following HTST, thermization, and microfluidization, particle size, rheology, confocal microscopy, microbiology, composition, and physical properties were determined.

Particle Size. Approximately $24 \mathrm{~h}$ after sample generation, particle size distributions were obtained in triplicate using a Partica laser scanning particle size distribution analyzer (model LA-950V2, Horiba Instruments, Kyoto, Japan). Particle size distribution was calculated based on median volume-weighted droplet size $[\mathrm{d}(4,3)]$ and median area-weighted droplet size $[d(3,2)]$.

Rheology. A Kinexus Lab Plus rheometer (Malvern Instruments, Westborough, MA) was used for obtaining strain, frequency, and time sweeps. Approximately $11.5 \mathrm{~mL}$ of sample was poured into the cup (PC25 C019AL) of a standard concentric cylinder attachment with a 25-mm diameter bob (C25 SW1399 SS) and a strain sweep was conducted to determine the linear viscoelastic range. A strain of $0.015 \%$ was selected to run frequency sweeps from 1 to $100 \mathrm{~Hz}$ at $20^{\circ} \mathrm{C}$ to determine viscosity, reported at $5 \mathrm{~Hz}$. Rheological changes with rennet addition were examined based on studies by Guinee et al. (1996) and Bittante (2011). A solution consisting of $2.00 \mathrm{~g}$ of Chy-Max Extra fermentation produced chymosin (Chr. Hansen, Milwaukee, WI) in $100 \mathrm{~mL}$ of water was prepared and $200 \mu \mathrm{L}$ was added to the $11.5-\mathrm{mL}$ sample. Time sweeps were run at $0.015 \%$ 
strain, $10 \mathrm{~Hz}$, and $35^{\circ} \mathrm{C}$. The sweeps usually lasted for $30 \mathrm{~min}$, although $60 \mathrm{~min}$ was used for samples that failed to coagulate within $30 \mathrm{~min}$. The time at which the elastic modulus $\left(\mathbf{G}^{\prime}\right)$ began to increase was selected as the coagulation time (Tunick, 2011). The $\mathrm{G}^{\prime}$ value at 30 or 60 min after enzyme addition was designated as the gel strength.

Microstructure. Milk samples were fixed with $2.5 \%$ glutaraldehyde solution (Electron Microscopy Sciences, Hatfield, PA) and examined using a TCS SPE confocal laser scanning microscope equipped with a $100-\mathrm{mm}$ oil immersion objective lens (Leica Microsystems, Buffalo Grove, IL), as previously described (Tunick et al., 2016). One hundred microliters of sample was vortexed with $3 \mu \mathrm{L}$ of $0.01 \%$ Fast Green FCF dye to stain proteins and $3 \mu \mathrm{L}$ of $0.01 \%$ Nile Red dye to stain lipids.

Milk gel formed in the rheometer was aligned by the oscillations and not judged to be representative. Instead, $100 \mu \mathrm{L}$ of the rennet solution was added to $11 \mathrm{~mL}$ of milk in a $35^{\circ} \mathrm{C}$ water bath and the resulting gel was taken for microscopy. The gel was fixed in $0.025 \%$ glutaraldehyde in $0.01 M$ imidazole (Electron Microscopy Sciences), rinsed in imidazole buffer, and dehydrated in a series of increasing ethanol (WarnerGraham, Cockeysville, MD) rinses. It was then critical point dried (Denton Vacuum, Cherry Hill, NJ). The samples were mounted on stubs, sputter gold coated (EMS 150R ES, Electron Microscopy Sciences), and viewed with a FEI Quanta 200 F scanning electron microscope (Hillsboro, OR).

Microbiology. Raw and processed milk samples were collected in sterile $15-\mathrm{mL}$ tubes and stored at $4^{\circ} \mathrm{C}$ for up to $3 \mathrm{~h}$ before plating. Serial dilutions of the milk were prepared using $1 \%$ peptone water, and $100 \mu \mathrm{L}$ of each dilution was spread plated on plate count agar (PCA, Oxoid, Basingtoke, UK). Enumeration of the total mesophilic aerobic bacteria was determined after incubation at $32^{\circ} \mathrm{C}$ for $48 \mathrm{~h}$. Psychrophilic bacterial counts were determined after incubation at $4^{\circ} \mathrm{C}$ for 7 d. Bacterial counts were reported as the mean colonyforming units per milliliter from a minimum of 2 plates.

Composition and Physical Properties. Protein, lipid, lactose, and TS contents of all milk samples were obtained in triplicate using near-infrared spectroscopy (MilkoScan Minor 6, FOSS North America Inc., Chicago, IL; method 972.16, AOAC Interational, 2012). Nitrogen content was determined in duplicate using a nitrogen analyzer (Flash EA1112; Thermo Fisher Scientific, Lakewood, NJ). Salt content was measured in duplicate using chloride titrator strips (Hach Co., Loveland, CO). Ash content was obtained in duplicate by drying samples overnight in a muffle furnace (Lindberg Furnace, Watertown, WI) set at $600^{\circ} \mathrm{C}$ (method 945.46; AOAC International, 2012). The $\mathrm{pH}$ was tracked with a model $611 \mathrm{pH}$ meter (Orion Research Corp., Cambridge, MA).

\section{Statistics}

Experiments were conducted using a split-plot generalized mixed model design, with milk heat treatments (raw, thermized, and pasteurized) as the whole-plot, processing treatments (control, homogenized control, and microfluidization at $42^{\circ} \mathrm{C} / 75 \mathrm{MPa}, 42^{\circ} \mathrm{C} / 125 \mathrm{MPa}$, $54^{\circ} \mathrm{C} / 125 \mathrm{MPa}$, and $54^{\circ} \mathrm{C} / 170 \mathrm{MPa}$ ) as the subplot fixed factors, and the block as the random factor. Composition and $\mathrm{pH}$ data were analyzed using PROC MIXED (version 14.1 SAS/STAT; SAS Institute Inc., Cary, $\mathrm{NC}$ ); a variance grouping technique was used to correct the variance heterogeneity noted for all variables. Particle size, milk viscosity, and coagulation properties data were analyzed using GLIMMIX (SAS/STAT). Means were compared using Sidak adjusted $P$-values to hold experiment-wise error at 0.05 .

\section{RESULTS AND DISCUSSION}

\section{Processing}

Raw milk obtained from a local dairy was taken from a full tanker waiting to unload, with subsequent analysis indicating fat content under $3.25 \%$ due to creaming. Therefore, heavy cream was purchased to standardize the raw milk to $3.0 \%$, which is commonly used in cheesemaking. Nonheated raw milk $(\mathbf{R})$, which is used by some raw milk cheese manufacturers, was selected as our control. Thermization (S)-treated milk, sometimes referred to as heat shock, was selected because it is a common mild heat treatment used to temporarily reduce spoilage bacteria if pasteurization is delayed, or for raw milk cheese manufacture. Pasteurized milk $(\mathbf{P})$ was selected because it is by far the most common heat treatment used for milk-based products. Inactivation of alkaline phosphatase, which indicates pasteurization conditions have been achieved (pass), was obtained for $\mathrm{P}$ and 2-stage homogenized $\mathrm{P}$ controls. Prior to microfluidization, $\mathrm{R}$ and $\mathrm{S}$ control samples, including 2-stage homogenized controls, failed.

A temperature increase directly dependent on the microfluidization pressure was observed. Treatment at $42^{\circ} \mathrm{C} / 75 \mathrm{MPa}$ resulted in a final average temperature (mean $\pm \mathrm{SE}$ ) of $56.6 \pm 1.6^{\circ} \mathrm{C}$, whereas $42^{\circ} \mathrm{C} / 125 \mathrm{MPa}$, $54^{\circ} \mathrm{C} / 125 \mathrm{MPa}$, and $54^{\circ} \mathrm{C} / 170 \mathrm{MPa}$ resulted in exit temperatures of $65.5 \pm 1.2,77.5 \pm 1.2$, and $83.9 \pm$ $1.0^{\circ} \mathrm{C}$, respectively. Further analysis indicated an increase of $2.0,1.88$, and $1.76^{\circ} \mathrm{C}$ per $10 \mathrm{MPa}$ increase in pressure for treatment at 75,125 , and $170 \mathrm{MPa}$, respectively. These results agree with previous work that 
Table 1. The split-plot ANOVA and mean comparisons for the median particle sizes [volume, $\mathrm{d}(4,3)$, and area, $\mathrm{d}(3,2)]$ using PROC GLIMMIXED with milk (whole-plot) and processing treatments ${ }^{1}$ (Trt; subplot) as the fixed factors and block as the random factor.

\begin{tabular}{|c|c|c|c|c|c|}
\hline \multirow[b]{2}{*}{ Source } & \multirow[b]{2}{*}{$\mathrm{df}$} & \multicolumn{2}{|c|}{$\mathrm{d}(4,3)$} & \multicolumn{2}{|c|}{$\mathrm{d}(3,2)$} \\
\hline & & F-value & $P$-value & F-value & $P$-value \\
\hline Milk & 2 & 0.26 & 0.7798 & 1.36 & 0.3248 \\
\hline Trt & 5 & $7,370.27$ & $<0.0001$ & 359.01 & $<0.0001$ \\
\hline Milk $\times$ Trt & 10 & 0.73 & 0.6933 & 1.10 & 0.3977 \\
\hline Residual & & 0.0020 & & 0.0429 & \\
\hline \multicolumn{6}{|c|}{ Median means $(\mu \mathrm{m})$ and comparisons } \\
\hline \multicolumn{6}{|c|}{ Trt } \\
\hline Control & & \multicolumn{2}{|c|}{$7.956^{\mathrm{a}}$} & \multicolumn{2}{|c|}{$7.921^{\mathrm{a}}$} \\
\hline Homogenized control & & \multicolumn{2}{|c|}{$5.165^{\mathrm{b}}$} & \multicolumn{2}{|c|}{$4.127^{\mathrm{b}}$} \\
\hline $42^{\circ} \mathrm{C} / 75 \mathrm{MPa}$ & & \multicolumn{2}{|c|}{$0.614^{\mathrm{c}}$} & \multicolumn{2}{|c|}{$0.501^{\mathrm{c}}$} \\
\hline $42^{\circ} \mathrm{C} / 125 \mathrm{MPa}$ & & \multicolumn{2}{|c|}{$0.508^{\mathrm{c}}$} & \multicolumn{2}{|c|}{$0.423^{\mathrm{c}}$} \\
\hline $54^{\circ} \mathrm{C} / 125 \mathrm{MPa}$ & & \multirow{2}{*}{\multicolumn{2}{|c|}{$\begin{array}{l}0.489^{\mathrm{c}} \\
0.477^{\mathrm{c}}\end{array}$}} & \multirow{2}{*}{\multicolumn{2}{|c|}{$\begin{array}{l}0.410^{\mathrm{c}} \\
0.390^{\mathrm{c}}\end{array}$}} \\
\hline $54^{\circ} \mathrm{C} / 170 \mathrm{MPa}$ & & & & & \\
\hline
\end{tabular}

shows a linear increase in exit temperature, typically 1.7 to $1.8^{\circ} \mathrm{C}$ per $10 \mathrm{MPa}$ (Pedras et al., 2012) during high-pressure homogenization of milk. The temperature increase is a result of the intense friction generated from the high pressure and shear as well as cavitation that occurs as milk is forced through the narrow impact chamber microchannels.

As pasteurizing inactivates the alkaline phosphatase enzyme, further processing with the microfluidizer should have no effect and all $\mathrm{P}$ samples passed. However, at $42^{\circ} \mathrm{C} / 75 \mathrm{MPa}, \mathrm{R}$ and $\mathrm{S}$ samples failed, yet both passed under the most extreme microfluidizing conditions used $\left(54^{\circ} \mathrm{C} / 170 \mathrm{MPa}\right)$. All 125-MPa samples passed, indicating a pasteurization-like effect resulting from the combination of modest inlet temperature (42 or $\left.54^{\circ} \mathrm{C}\right)$, high pressure $(125$ or $170 \mathrm{MPa})$, shear, cavitation, and turbulence experienced during microfluidization.

\section{Physical and Chemical Properties}

Particle Size. Table 1 shows the median volumes and areas of the particles in the milk samples. As expected, 2-stage homogenization (2-stage, $10 \mathrm{MPa} / 5 \mathrm{MPa})$ decreased the particle sizes $(P<0.05)$ whereas heat treatment alone resulted in no significant differences among $\mathrm{R}$, $\mathrm{S}$, or $\mathrm{P}$ milk samples. Two-pass microfluidization reduced the median sizes further $(P<0.05)$, resulting in $\mathrm{d}(3,2)$ values ranging from 0.390 to $0.501 \mu \mathrm{m}$, nearly 20 times smaller than controls. A similar trend was observed in the $\mathrm{d}(4,3)$ values. Previous work showed single-pass microfluidization at 100 or $150 \mathrm{MPa}$ yielded a median $\mathrm{d}(3,2)$ value of $0.26 \mu \mathrm{m}$, a reduction of approximately 10 fold (Olson et al., 2004). This indicates that multiple passes can provide additional particle size reduction. However, preliminary data also showed that 3 or more passes provided no further reduction, suggesting that the optimum number of passes to obtain a minimum particle size is 2 . Our results also showed that both the median $\mathrm{d}(3,2)$ and $\mathrm{d}(4,3)$ sizes decreased as microfluidization pressure and inlet temperature increased, although the differences were not significant $(P>0.05)$. The lack of further reduction in particle size with increasing microfluidization pressure has been attributed to cluster formation (Olson et al., 2004). The reader is directed to the Microstructure section for further discussion of cluster formation.

Rheology. Complex viscosity of the milk samples taken at $5 \mathrm{~Hz}$ ranged from 0.04 to $0.09 \mathrm{~Pa} \cdot \mathrm{s}$; only nonhomogenized control and $54^{\circ} \mathrm{C} / 125 \mathrm{MPa}$ samples were significantly different $(P<0.05)$, as shown in Table 2 . However, the $54^{\circ} \mathrm{C}$ treatments tended to have higher viscosities, which may suggest the higher pressure and outlet temperature were initiating the denaturation of $\beta-\mathrm{LG}$, the primary whey protein found in milk. Not only is the exit temperature resulting from microfluidizing at $54^{\circ} \mathrm{C}$ and 125 or $170 \mathrm{MPa}(77.5 \pm 1.2$ or $83.9 \pm$ $1.0^{\circ} \mathrm{C}$ respectively) near or exceeding the denaturation temperature of $\beta$-LG, the intense shear, cavitation, and turbulence experienced further destabilizes the protein. Increasing levels of denatured $\beta-L G$ and formation of $\kappa$-CN- $\beta$-LG complexes will influence gelation properties.

In addition, Table 2 shows the rheological results from the coagulation experiments. Coagulation time, the point at which the $\mathrm{G}^{\prime}$ values began to increase after rennet addition, was the only property that showed significant differences among the $\mathrm{R}, \mathrm{S}$, and $\mathrm{P}$ milk 
Table 2. The split-plot ANOVA and mean comparisons for the milk complex viscosity, coagulation time after chymosin addition (log coagulation time), and gel elastic modulus $\left(\mathrm{G}^{\prime}\right)$ at 30 (controls and $42^{\circ} \mathrm{C}$ microfluidized treatments) or $60\left(54^{\circ} \mathrm{C}\right.$ microfluidized treatments) min after chymosin addition using PROC MIXED ${ }^{1}$ with milk (whole-plot) and processing treatments (Trt; subplot) as the fixed factors, and block as the random factor ${ }^{2}$

\begin{tabular}{|c|c|c|c|c|c|c|c|c|c|c|c|c|}
\hline \multirow[b]{2}{*}{ Source } & \multirow[b]{2}{*}{ df } & \multicolumn{3}{|c|}{ Milk } & \multicolumn{8}{|c|}{ Milk gel } \\
\hline & & F-value & $P$-value & $\mathrm{Pa} \cdot \mathrm{s}$ & F-value & $P$-value & $\mathrm{R}$ & $\mathrm{S}$ & $\mathrm{P}$ & F-value & $P$-value & $\mathrm{Pa}$ \\
\hline Milk & 2 & 1.34 & 0.2793 & & 3.76 & 0.0522 & & & & 2.69 & 0.0960 & \\
\hline Trt & 5 & 3.91 & 0.0082 & & 78.98 & $<0.0001$ & & & & 42.82 & $<0.001$ & \\
\hline Control & & & & $0.03^{\mathrm{b}}$ & & & $232^{\mathrm{d}, \mathrm{y}}$ & $332^{\mathrm{c}, \mathrm{x}}$ & $355^{\mathrm{bc}, \mathrm{x}}$ & & & $52.6^{\mathrm{a}}$ \\
\hline Homogenized control & & & & $0.04^{\mathrm{ab}}$ & & & $269^{\mathrm{d}, \mathrm{x}}$ & $253^{\mathrm{c}, \mathrm{x}}$ & $329^{\mathrm{c}, \mathrm{x}}$ & & & $59.1^{\mathrm{a}}$ \\
\hline $42^{\circ} \mathrm{C} / 75 \mathrm{MPa}$ & & & & $0.04^{\mathrm{ab}}$ & & & $128^{\mathrm{d}, \mathrm{y}}$ & $277^{\mathrm{c}, \mathrm{xy}}$ & $306^{\mathrm{c}, \mathrm{x}}$ & & & $65.9^{\mathrm{a}}$ \\
\hline $42^{\circ} \mathrm{C} / 125 \mathrm{MPa}$ & & & & $0.04^{\mathrm{ab}}$ & & & $424^{\mathrm{c}, y}$ & $493^{\mathrm{b}, \mathrm{xy}}$ & $581^{\mathrm{ab}, \mathrm{x}}$ & & & $25.8^{\mathrm{b}}$ \\
\hline $54^{\circ} \mathrm{C} / 125 \mathrm{MPa}$ & & & & $0.09^{\mathrm{a}}$ & & & $1,899^{\mathrm{a}, \mathrm{x}}$ & $1,399^{\mathrm{a}, \mathrm{y}}$ & $1,135^{\mathrm{a}, \mathrm{xy}}$ & & & $10.3^{\mathrm{c}}$ \\
\hline
\end{tabular}

${ }^{\mathrm{a}-\mathrm{d}}$ Processing treatment means in same column with different superscript letters are statistically different $(P<0.05)$.

${ }^{\mathrm{x}, \mathrm{y}}$ Processing treatment means in the same row for the log coagulation time property within milk with different superscript letters are statistically different $(P<0.05)$.

${ }^{1}$ SAS/STAT (SAS Institute Inc., Cary, NC).

${ }^{2}$ The Trt included control milk, homogenized control milk, and milk microfluidized at different inlet temperatures $\left({ }^{\circ} \mathrm{C}\right)$ and pressures $(\mathrm{MPa})$.

${ }^{3} \mathrm{R}=$ raw; $\mathrm{S}=$ thermized; $\mathrm{P}=$ pasteurized.

samples. Control and $42^{\circ} \mathrm{C} / 75 \mathrm{MPa}$ milk samples coagulated within 5 min, whereas $54^{\circ} \mathrm{C}$ and 125 or 170 $\mathrm{MPa}$ treatments required 12 to $32 \mathrm{~min}$ to coagulate and in several cases failed. This suggests the weak gels that formed at higher pressures and inlet temperatures contained damaged protein particles. This damage may have been caused by disruption of casein micelles, denaturation of whey proteins, and protein absorbing onto the surface of fat droplets (Tosh and Dalgleish, 1998). Studies have reported slower coagulation times, weaker gel strengths, and poor syneresis when microfluidized milk was used to make hard (Lemay et al., 1994) or semihard cheeses (Van Hekken et al., 2007). However, some cheeses require homogenized milk, and microfluidization may be beneficial to producing high-moisture cheeses with short body, such as Queso Fresco.

Microstructure. Confocal images of the milk samples are shown in Figures 2 and 3. Milk that was not homogenized or microfluidized exhibited fat globules with diameters in the 2 to $8 \mu \mathrm{m}$ range. Two-stage homogenization reduced the average median size to 2 $\mu \mathrm{m}$. However, $24 \mathrm{~h}$ after microfluidization, noticeable agglomerations of $1 \mu \mathrm{m}$ and 1 to $3 \mu \mathrm{m}$ for $54^{\circ} \mathrm{C} / 125$ $\mathrm{MPa}$ and $54^{\circ} \mathrm{C} / 170 \mathrm{MPa}$, respectively, were seen scattered in samples (white arrows in Figures 2e, 2f, 3e, and 3f). As microfluidization ruptures the milk fat globular membrane, hydrophobic and hydrophilic components in milk are forcibly dispersed throughout the solution. As this is an unfavorable thermodynamic state, the scattered fat droplets will coalesce over time.

Milk gels formed by rennet coagulation, analyzed by scanning electron microscopy, revealed a matrix of casein with openings corresponding to voids that would hold free serum (whey) and areas vacated by fat droplets during sample preparation (Figures 4-5). Control and 2-stage homogenized milk matrices were typical of coagulated milk gels containing protein networks with large entrapped fat droplets (Figure 4a, 4b, 5a, and $5 \mathrm{~b}$ ). Microfluidization further reduced the size of the fat droplets, resulting in a network of protein with entrapped fat droplets (Figure $4 \mathrm{c}-\mathrm{f}, 5 \mathrm{c}-\mathrm{f}$ ). Casein particles, which originally averaged $0.25 \mu \mathrm{m}$, were also reduced approximately 10 fold. Additionally, open spaces in the micrographs that corresponded to fat droplets or serum channels decreased in size, giving the matrix a more homogeneous appearance.

Microbiology. The indigenous mesophilic microflora within the $\mathrm{R}$ samples varied slightly, with a mean value of $3.96 \pm 0.38 \mathrm{log} \mathrm{cfu} / \mathrm{mL}$. In $\mathrm{S}$ or $\mathrm{P}$ milk, the microbial load decreased to $2.74 \pm 0.58$ or $1.62 \pm 1.1$ $\log \mathrm{cfu} / \mathrm{mL}$, respectively. Psychrophilic bacteria were also present in $\mathrm{R}$ samples at $3.8 \pm 0.98 \log \mathrm{cfu} / \mathrm{mL}$, but not detected in $\mathrm{S}$ or $\mathrm{P}$ milk. Two-stage homogenization $(10 \mathrm{MPa} / 5 \mathrm{MPa})$ was also performed and did not alter 

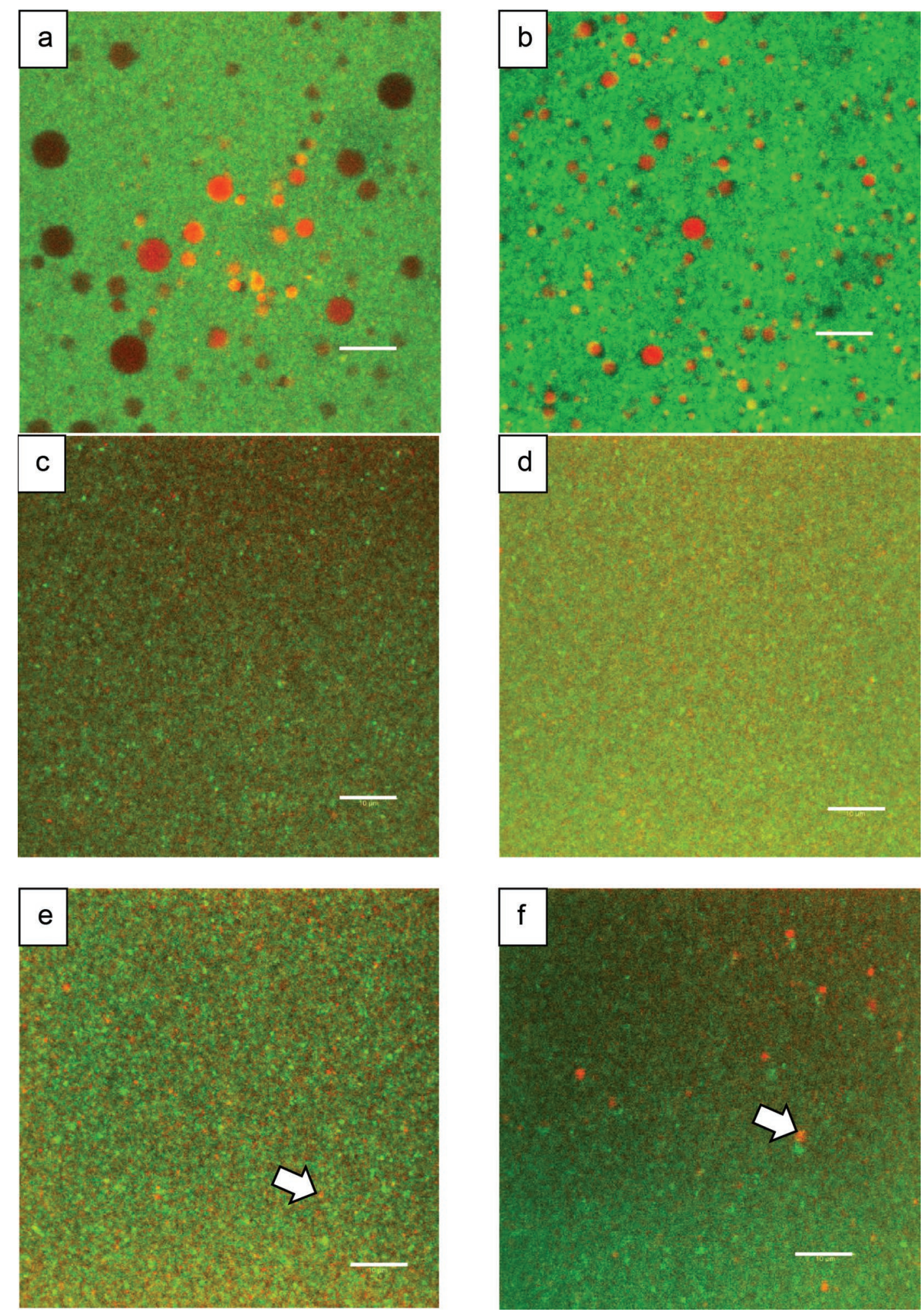

Figure 2. Confocal laser scanning microscopy images of (a) raw milk (R), (b) homogenized R, and R microfluidized at (c) $42^{\circ} \mathrm{C} / 75 \mathrm{MPa}$, (d) $42^{\circ} \mathrm{C} / 125 \mathrm{MPa}$, (e) $54^{\circ} \mathrm{C} / 125 \mathrm{MPa}$, and (f) $54^{\circ} \mathrm{C} / 170 \mathrm{MPa}$. Arrows indicate agglomerated fat droplets. Red and yellow areas correspond to fat droplets and green areas to protein. Bars represent $10 \mu \mathrm{m}$. Color version available online. 

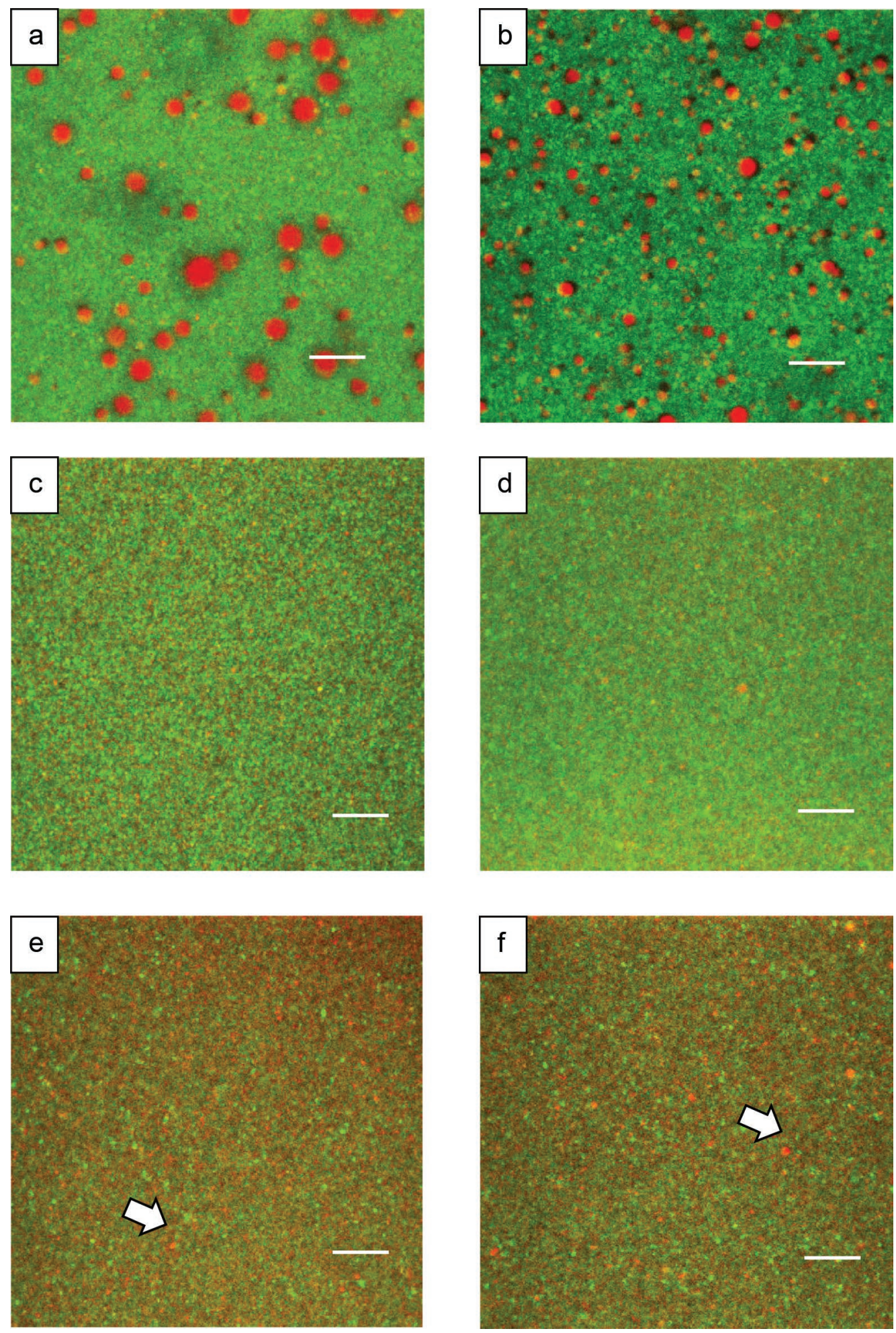

Figure 3. Confocal laser scanning microscopy images of (a) thermization (S), (b) homogenized $\mathrm{S}$, and $\mathrm{S}$ microfluidized at (c) $42^{\circ} \mathrm{C} / 75 \mathrm{MPa}$, (d) $42^{\circ} \mathrm{C} / 125 \mathrm{MPa}$, (e) $54^{\circ} \mathrm{C} / 125 \mathrm{MPa}$, and (f) $54^{\circ} \mathrm{C} / 170 \mathrm{MPa}$. Arrows indicate agglomerated fat droplets. Red and yellow areas correspond to fat droplets and green to protein. Images of pasteurized milk were similar. Bars represent $10 \mu \mathrm{m}$. Color version available online. 

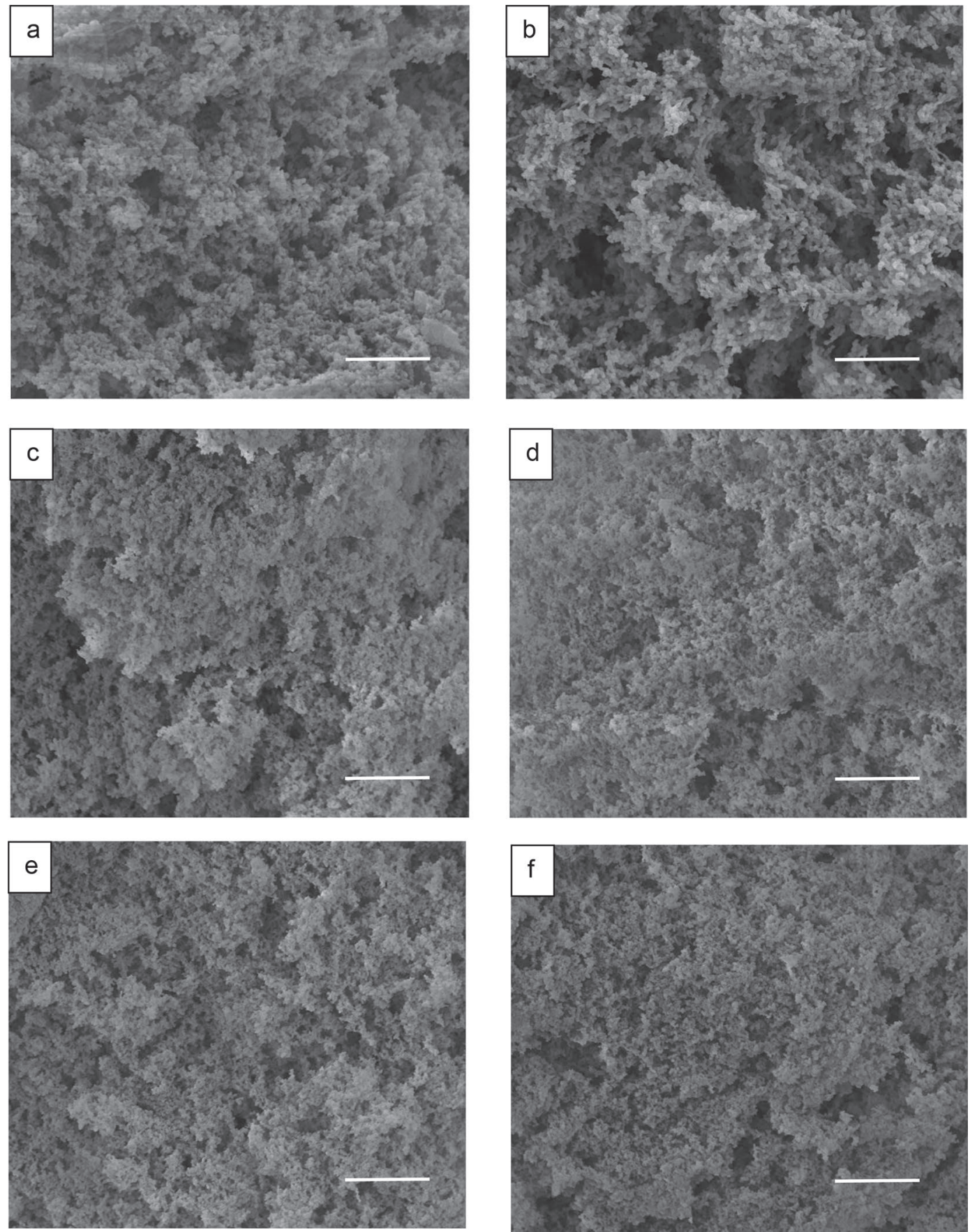

Figure 4. Scanning electron micrographs of coagulated curd from (a) raw milk (R), (b) homogenized R, and $\mathrm{R}$ microfluidized at (c) $42^{\circ} \mathrm{C} / 75$ $\mathrm{MPa}$, (d) $42^{\circ} \mathrm{C} / 125 \mathrm{MPa}$, (e) $54^{\circ} \mathrm{C} / 125 \mathrm{MPa}$, and (f) $54^{\circ} \mathrm{C} / 170 \mathrm{MPa}$. Lighter regions correspond to protein and darker regions to voids and areas that had been occupied by fat droplets. Bars represent $5 \mu \mathrm{m}$.

the microbial count within all 3 milk samples $(\mathrm{R}, \mathrm{S}$, and $\mathrm{P})$.

Prior to microfluidization, milk samples were stored at $4^{\circ} \mathrm{C}$ for up to $2 \mathrm{~d}$, and the number of mesophilic and psychrophilic bacteria increased by as much as 2.5 and $2 \mathrm{log}$, respectively. After processing at $42^{\circ} \mathrm{C}$ and
$75 \mathrm{MPa}$, the number of mesophilic bacteria remained similar to R milk, at $3.27 \pm 0.57 \mathrm{cfu} / \mathrm{mL}$; however, the number of psychrophilic bacteria was below the detection limit of $1.0 \log \mathrm{cfu} / \mathrm{mL}$. Increasing the pressure to $125 \mathrm{MPa}$ resulted in a 1.3-log decrease in the mesophilic count from $\mathrm{R}$ milk, but less of a decrease $(\leq 0.5$ 

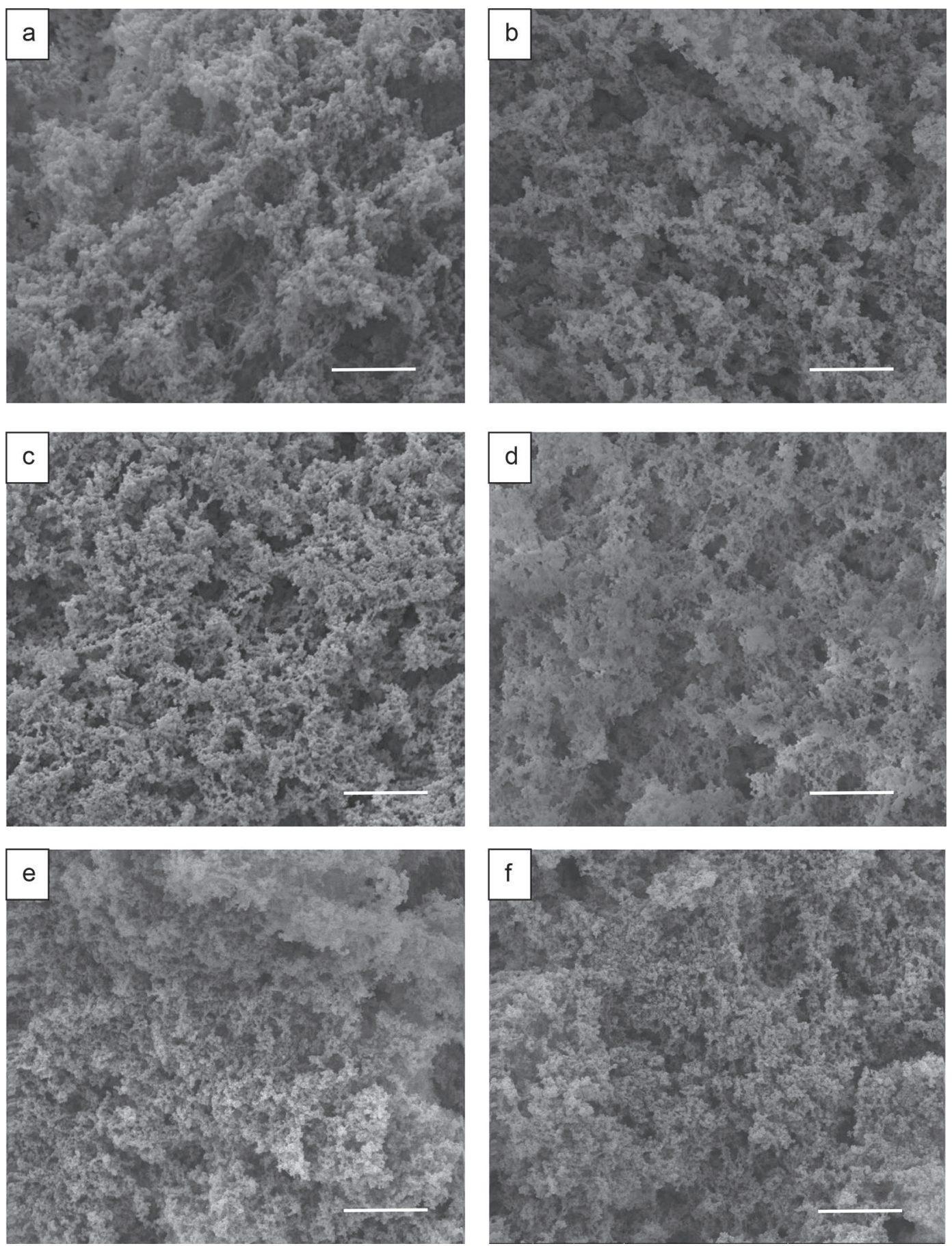

Figure 5. Scanning electron micrographs of coagulated curd from (a) pasteurized milk (P), (b) homogenized P, and P microfluidized at (c) $42^{\circ} \mathrm{C} / 75 \mathrm{MPa}$, (d) $42^{\circ} \mathrm{C} / 125 \mathrm{MPa}$, (e) $54^{\circ} \mathrm{C} / 125 \mathrm{MPa}$, and (f) $54^{\circ} \mathrm{C} / 170 \mathrm{MPa}$. Lighter areas correspond to protein and darker areas to voids and places that had been occupied by fat droplets. Micrographs of curd from thermization treated milk were similar. Bars represent $5 \mu \mathrm{m}$.

$\log$ ) for $\mathrm{S}$ and $\mathrm{P}$ samples treated at $42^{\circ} \mathrm{C} / 125 \mathrm{MPa}$. By raising the input temperature to $54^{\circ} \mathrm{C}$ and maintaining a pressure of $125 \mathrm{MPa}$, the number of mesophiles in $\mathrm{R}$ milk dropped by $2.5 \mathrm{log}$ and was below the limit of detection (1 log cfu/mL) in S and P milk. The most ex- treme processing condition $\left(54^{\circ} \mathrm{C} / 170 \mathrm{MPa}\right)$ decreased the mesophilic count in $2 \mathrm{R}$ samples below the level of detection, whereas 1 sample maintained a count of 1.77 $\mathrm{cfu} / \mathrm{mL}$. 
Table 3. The split-plot ANOVA and mean comparison for the composition and pH using PROC MIXED ${ }^{1}$ with milk (whole-plot) and processing treatments (Trt; subplot) as the fixed factors, and block as the random factor ${ }^{2}$

\begin{tabular}{|c|c|c|c|c|c|c|c|c|c|c|c|c|c|}
\hline \multirow[b]{2}{*}{ Source } & \multirow[b]{2}{*}{$\mathrm{df}$} & \multicolumn{2}{|c|}{ Fat } & \multicolumn{2}{|c|}{ Protein } & \multicolumn{2}{|c|}{ Lactose } & \multicolumn{2}{|c|}{ Ash } & \multicolumn{2}{|c|}{$\mathrm{TS}$} & \multicolumn{2}{|c|}{$\mathrm{pH}$} \\
\hline & & F-value & $P$-value & F-value & $P$-value & F-value & $P$-value & F-value & $P$-value & F-value & $P$-value & F-value & $P$-value \\
\hline Milk & 2 & 2.91 & 0.1024 & 1.32 & 0.3147 & 0.42 & 0.6785 & 0.22 & 0.8089 & 3.54 & 0.0755 & 3.07 & 0.0688 \\
\hline Trt & 5 & 7.42 & 0.0005 & 355.30 & $<0.0001$ & 21.25 & $<0.0001$ & 2.87 & 0.0392 & 42.58 & $<0.0001$ & 3.18 & 0.0206 \\
\hline Milk $\times$ Trt & 10 & 1.41 & 0.2460 & 0.66 & 0.7456 & 0.92 & 0.5355 & 0.78 & 0.6506 & 0.75 & 0.6719 & 0.89 & 0.5535 \\
\hline \multicolumn{14}{|c|}{ Composition and $\mathrm{pH}$ means } \\
\hline Control & \multicolumn{3}{|c|}{$3.17^{\mathrm{a}}$} & \multicolumn{2}{|c|}{$3.14^{\mathrm{a}}$} & \multicolumn{2}{|c|}{$4.90^{\mathrm{a}}$} & \multicolumn{2}{|c|}{$0.70^{\mathrm{a}}$} & \multicolumn{2}{|c|}{$11.95^{\mathrm{a}}$} & \multicolumn{2}{|c|}{$6.55^{\mathrm{a}}$} \\
\hline Homogenized control & \multicolumn{3}{|c|}{$3.16^{\mathrm{a}}$} & \multicolumn{2}{|c|}{$3.13^{\mathrm{a}}$} & \multicolumn{2}{|c|}{$4.79^{\mathrm{ab}}$} & \multicolumn{2}{|c|}{$0.70^{\mathrm{ab}}$} & \multicolumn{2}{|c|}{$11.84^{\mathrm{a}}$} & \multicolumn{2}{|c|}{$6.44^{\mathrm{b}}$} \\
\hline $42^{\circ} \mathrm{C} / 75 \mathrm{MPa}$ & \multicolumn{3}{|c|}{$3.06^{\mathrm{ab}}$} & \multicolumn{2}{|c|}{$2.33^{\mathrm{b}}$} & \multicolumn{2}{|c|}{$4.76^{\mathrm{b}}$} & \multicolumn{2}{|c|}{$0.69^{\mathrm{ab}}$} & \multicolumn{2}{|c|}{$11.46^{\mathrm{b}}$} & \multicolumn{2}{|c|}{$6.50^{\mathrm{ab}}$} \\
\hline $42^{\circ} \mathrm{C} / 125 \mathrm{MPa}$ & \multicolumn{3}{|c|}{$3.08^{\mathrm{ab}}$} & \multicolumn{2}{|c|}{$2.21^{\mathrm{b}}$} & \multicolumn{2}{|c|}{$4.73^{\mathrm{b}}$} & \multicolumn{2}{|c|}{$0.69^{\mathrm{ab}}$} & \multicolumn{2}{|c|}{$11.41^{\mathrm{b}}$} & \multicolumn{2}{|c|}{$6.53^{\mathrm{ab}}$} \\
\hline $54^{\circ} \mathrm{C} / 125 \mathrm{MPa}$ & \multicolumn{3}{|c|}{$3.03^{\mathrm{b}}$} & \multicolumn{2}{|c|}{$2.23^{\mathrm{b}}$} & 4.7 & & 0.6 & $69^{\mathrm{ab}}$ & 11. & $.37^{\mathrm{b}}$ & & $50^{\mathrm{ab}}$ \\
\hline $54^{\circ} \mathrm{C} / 170 \mathrm{MPa}$ & & & $03^{\mathrm{b}}$ & 2.2 & $29^{\mathrm{b}}$ & 4.7 & & 0.6 & $68^{\mathrm{b}}$ & 11. & $.42^{\mathrm{b}}$ & & $47^{\mathrm{b}}$ \\
\hline
\end{tabular}

${ }^{\mathrm{a}, \mathrm{b}}$ Processing treatment means within the same column with different letters are statistically different $(P<0.05)$.

${ }^{1}$ SAS/STAT (SAS Institute Inc., Cary, NC).

${ }^{2}$ Processing treatments include control milk, homogenized control milk, and milk microfluidized at different inlet temperatures $\left({ }^{\circ} \mathrm{C}\right)$ and pressures $(\mathrm{MPa})$.

Composition and $\boldsymbol{p H}$. Table 3 shows the results from compositional analysis of all samples. We found no differences $(P>0.05)$ in the fat, lactose, ash, and $\mathrm{pH}$ of the milk samples. However, when compared with controls, a lower apparent protein content was observed in microfluidized samples, which influenced TS. This is a result of the unique protein-fat interactions brought on by microfluidization. Coupled with the emulsions generated by microfluidizing, we suspect that near infrared spectroscopy calibrated with pasteurized-homogenized standards will not correctly identify protein embedded in fat. To further support this claim, we observed no differences $(P>0.05)$ in total nitrogen content across microfluidization treatments. Composition, except for protein, was within the expected values for milk standardized to $3.0 \%$.

\section{CONCLUSIONS}

Novel cheese milk were generated from raw, thermized, and pasteurized milk that were microfluidized under 4 processing treatments, $42^{\circ} \mathrm{C} / 75 \mathrm{MPa}, 42^{\circ} \mathrm{C} / 125 \mathrm{MPa}$, $54^{\circ} \mathrm{C} / 125 \mathrm{MPa}$, and $54^{\circ} \mathrm{C} / 170 \mathrm{MPa}$. Samples showed no change in composition except for an apparent reduction in protein. Fat droplet size was reduced to 0.390 to $0.501 \mu \mathrm{m}$, and confocal microscopy revealed a fine emulsion with scattered agglomerations, 1 to $3 \mu \mathrm{m}$ in size. Coagulation properties of the milk treated at $54^{\circ} \mathrm{C}$ and 125 or $170 \mathrm{MPa}$ displayed longer coagulation times and weaker gels. Microscopy of the gels formed from microfluidized milk showed a dense matrix with welldispersed fat-protein droplets. Therefore, milk treated via microfluidization at $75 \mathrm{MPa}$ may be useful for the production of short curd, high-moisture cheeses made from homogenized milk. However, higher pressures alter coagulation properties and may be useful in the production of novel dairy-based ingredients.

\section{ACKNOWLEDGMENTS}

The authors thank ARS scientists Andre White, Raymond Kwoczak, Susan Iandola, Joseph Uknalis, Brien Sullivan, and Laura Cerro for their contributions to this study, with special thanks to Mary Camp, ARS Northeast Area, for her statistical endeavors. We also thank the Wawa dairy in Wawa, Pennsylvania, for supplying the milk used in this study. Mention of trade names or commercial products in this paper is solely for the purpose of providing specific information and does not imply recommendation or endorsement by the USDA; USDA is an equal opportunity provider and employer.

\section{REFERENCES}

AOAC International. 2012. Official Methods of Analysis, 19th ed. AOAC Int., Gaithersburg, MD.

Bittante, G. 2011. Modeling rennet coagulation time and curd firmness of milk. J. Dairy Sci. 94:5821-5832. https://doi.org/10.3168/ jds.2011-4514.

Ciron, C. I. E., V. L. Gee, A. L. Kelly, and M. A. E. Auty. 2011. Effect of microfluidization of heat-treated milk on rheology and sensory properties of reduced fat yoghurt. Food Hydrocoll. 25:1470-1476. https://doi.org/10.1016/j.foodhyd.2011.02.012.

Ciron, C. I. E., V. L. Gee, A. L. Kelly, and M. A. E. Auty. 2012. Modifying the microstructure of low-fat yoghurt by microfluidisation of milk at different pressures to enhance rheological and sensory properties. Food Chem. 130:510-519. https://doi.org/10.1016/j .foodchem.2011.07.056.

Dairy Management Inc. (DMI). 2017. DMI quarterly retail snapshot: Milk Q1 2017. Accessed August 2017. https://mmistorebrands .com/wp-content/uploads/2017/11/DMI-Quarterly-Milk -Snapshot-Q1-2017.pdf.

Dalgleish, D. G., S. M. Tosh, and S. West. 1996. Beyond homogenization: the formation of very small emulsion droplets during 
the processing of milk by a microfluidizer. Neth. Milk Dairy J. 50:135-148.

Devi, A. F., R. Buckow, Y. Hemar, and S. Kasapis. 2013. Structuring dairy systems through high pressure processing. J. Food Eng. 114:106-122. https://doi.org/10.1016/j.jfoodeng.2012.07.032.

Dumay, E., D. Chevalier-Lucia, L. Picart-Palmade, A. Benzaria, A. Gràcia-Julià, and C. Blayo. 2013. Technological aspects and potential applications of (ultra) high-pressure homogenisation. Trends Food Sci. Technol. 31:13-26. https://doi.org/10.1016/j.tifs.2012.03 .005 .

Erkmen, O., and S. Karatas. 1997. Effect of high hydrostatic pressure on Staphylococcus aureus in milk. J. Food Eng. 33:257-262. https://doi.org/10.1016/S0260-8774(97)00021-6.

Guinee, T. P., D. J. O'Callaghan, P. D. Pudja, and N. O'Brien. 1996. Rennet coagulation properties of retentates obtained by ultrafiltration of skim milks heated to different temperatures. Int. Dairy J. 6:581-596. https://doi.org/10.1016/0958-6946(95)00061-5.

Lemay, A., P. Paquin, and C. Lacroix. 1994. Influence of microfluidization of milk on Cheddar cheese composition, color, texture, and yield. J. Dairy Sci. 77:2870-2879. https://doi.org/10.3168/jds .S0022-0302(94)77227-1.

Mohan, M. S., R. Ye, and F. Harte. 2016. Initial study on high pressure jet processing using a modified waterjet on physicochemical and rennet coagulation properties of pasteurized skim milk. Int. Dairy J. 55:52-58. https://doi.org/10.1016/j.idairyj.2015.12.004.

Olson, D. W., C. H. White, and R. L. Richter. 2004. Effect of pressure and fat content on particle sizes in microfluidized milk. J. Dairy Sci. 87:3217-3223. https://doi.org/10.3168/jds.S0022 $-0302(04) 73457-8$.

Patterson, M. F. 2005. Microbiology of pressure-treated foods. J. Appl. Microbiol. 98:1400-1409. https://doi.org/10.1111/j.1365 $-2672.2005 .02564 . \mathrm{x}$.

Pedras, M. M., C. R. G. Pinho, A. A. L. Tribst, M. A. Franchi, and M. Cristianini. 2012. The effect of high pressure homogenization on microorganisms in milk. Int. Food Res. J. 19:1-5. https://doi .org/10.1016/S0168-1605(02)00054-5.
Styles, M. F., D. G. Hoover, and D. F. Farkas. 1991. Response of Listeria monocytogenes and Vibrio parahaemolyticus to high hydrostatic pressure. J. Food Sci. 56:1404-1407.

Tomasula, P. M., and M. F. Kozempel. 2004. Flow characteristics of a pilot-scale high temperature, short time pasteurizer. J. Dairy Sci. 87:2761-2768. https://doi.org/10.3168/jds.S0022-0302(04)73403 $-7$.

Tomasula, P. M., J. A. Renye, D. L. Van Hekken, M. H. Tunick, R. Kwoczak, M. Toht, L. N. Leggett, J. B. Luchansky, A. C. S. PortoFett, and J. G. Phillips. 2014. Effect of high-pressure processing on reduction of Listeria monocytogenes in packaged Queso Fresco. J. Dairy Sci. 97:1281-1295. https://doi.org/10.3168/jds.2013-7538.

Tosh, S. M., and D. G. Dalgleish. 1998. The physical properties and renneting characteristics of the synthetic membrane on the fat globules of microfluidized milk. J. Dairy Sci. 81:1840-1847. https://doi.org/10.3168/jds.S0022-0302(98)75754-6.

Tunick, M. H. 2011. Small-strain rheology of food protein networks. J. Agric. Food Chem. 59:1481-1486.

Tunick, M. H., D. X. Ren, D. L. van Hekken, L. Bonnaillie, M. Paul, R. Kwoczak, and P. M. Tomasula. 2016. Effect of heat and homogenization on in vitro digestion of milk. J. Dairy Sci. 99:4124-4139. https://doi.org/10.3168/jds.2015-10474.

US Food and Drug Administration (FDA). 2017. Code of Federal Regulations, Title 21CFR1240.61. Accessed Sep. 8, 2017. https://www .ecfr.gov/cgi-bin/text-idx?SID =af76cdf3f94e03c0f24cffa2ac017fe1 $\&$ pitd $=20170908 \&$ node $=$ pt21.8.1240\&rgn $=\operatorname{div} 5 \#$ se21.8.1240 161.

Van Boekel, M. J. S. 1998. Effect of heating on Maillard reaction in milk. Food Chem. 62:403-414.

Van Hekken, D. L., M. H. Tunick, E. L. Malin, and V. H. Holsinger. 2007. Rheology and melt characterization of low-fat and full fat Mozzarella cheese made from microfluidized milk. Lebensm. Wiss. Technol. 40:89-98. https://doi.org/10.1016/j.lwt.2005.08.005. 